\title{
Ovarian follicular dynamics of Nelore (Bos indicus) cows subjected to a fixed-time artificial insemination protocol with injectable progesterone
}

\section{Dinâmica folicular ovariana de vacas Nelore (Bos indicus) submetidas a um protocolo de inseminação artificial em tempo fixo com progesterona injetável}

\author{
Fábio Morotti ${ }^{1}$; Jefferson Tadeu Campos ${ }^{1}$; Eduardo Raele Oliveira ${ }^{1}$; \\ Marcelo Marcondes Seneda ${ }^{2 *}$
}

\begin{abstract}
This study aims to evaluate ovarian follicular dynamics of Nelore cows subjected to fixed-time artificial insemination (FTAI) with injectable progesterone (P4) or intravaginal device. In the device group, 20 cows received an intravaginal device with $1 \mathrm{~g}$ P4 and administration of $2 \mathrm{mg}$ estradiol benzoate (EB) intramuscularly (im) on D0. The device was removed on D8, followed by administration of $500 \mu \mathrm{g}$ cloprostenol, $300 \mathrm{IU}$ equine chorionic gonadotropin (eCG) and $1 \mathrm{mg}$ estradiol cypionate (EC), im. The cows were inseminated $48 \mathrm{~h}$ later. In the injectable group, $350 \mathrm{mg}$ P4 (300 mg subcutaneously and $50 \mathrm{mg} \mathrm{im}$ ) and $2 \mathrm{mg}$ EB im were administered on D0 to 16 cows. On D6, $500 \mu \mathrm{g}$ cloprostenol, 300 IU eCG and $1 \mathrm{mg}$ EC were administered im. The FTAI was performed $48 \mathrm{~h}$ later. Sixty-five percent of cows from the device group (13/20) and $75 \%$ from the injectable group (12/16) showed follicles $\geq 5 \mathrm{~mm}$ on D4 ( $>0.05$ ). The average rate of follicular growth was $0.92 \pm 0.25 \mathrm{~mm} /$ day for the device group and $1.06 \pm 0.45 \mathrm{~mm} /$ day for the injectable group $(\mathrm{p}>0.05)$. The average diameter of the dominant follicle (DF) at FTAI was $11.4 \pm 1.4 \mathrm{~mm}$ for the device group and $10.8 \pm 1.8 \mathrm{~mm}$ for the injectable group $(\mathrm{p}>0.05)$. In the device group, ovulatory follicles (OF) had an average diameter of $12.1 \pm 1.4 \mathrm{~mm}$, and in the injectable group $12.3 \pm 1.6 \mathrm{~mm}(\mathrm{p}>0.05)$. Ninety percent of the device group $(18 / 20)$ and $37.5 \%$ of the injectable group $(6 / 16)$ demonstrated ovulation $(\mathrm{p}<0.05)$. The average diameter of the corpus luteum (CL) was $18.7 \pm 4.3 \mathrm{~mm}$ for the device group and $17.7 \pm 3.6 \mathrm{~mm}$ for the injectable group. The injectable $\mathrm{P} 4$ showed similarity in the presence of follicles $\geq 5 \mathrm{~mm}$ on D4, follicular growth rate, diameters of the $\mathrm{DF}, \mathrm{OF}$ and CL. However, the ovulation rate was higher in the device group.

Key words: Bos indicus, ultrasonography, follicular growth, ovulation, dominant follicle
\end{abstract}

\section{Resumo}

O objetivo deste estudo foi avaliar a dinâmica folicular ovariana de vacas Nelore submetidas à inseminação artificial em tempo fixo (IATF) com progesterona injetável (P4) ou dispositivo intravaginal. No grupo dispositivo, 20 vacas receberam um dispositivo intravaginal com $1 \mathrm{~g} \mathrm{P} 4 \mathrm{e} 2 \mathrm{mg}$ benzoato de estradiol (BE) por via intramuscular (im) no D0. No D8 o dispositivo foi removido e $500 \mu \mathrm{g}$ cloprostenol, 300 UI gonadotrofina coriônica equina (eCG) e $1 \mathrm{mg}$ cipionato de estradiol (CE) foram aplicados, im. As vacas foram inseminadas $48 \mathrm{~h}$ após o CE. No grupo injetável, 16 vacas receberam $350 \mathrm{mg} \mathrm{P4}(300 \mathrm{mg}$,

\footnotetext{
${ }^{1}$ Discentes de Doutorado do Programa de Pós-Graduação em Ciência Animal, Universidade Estadual de Londrina, UEL, Londrina, PR, Brasil. E-mail: fabiomorotti@hotmail.com; jeffersomcampos@seromtel.com.br; duraele@yahoo.com.br

${ }^{2}$ Prof. do Dept ${ }^{\circ}$ de Clínicas Veterinárias, Centro de Ciências Agrárias, UEL, Londrina, PR, Brasil. E-mail: mseneda@uel.br

* Author for correspondence
} 
subcutânea e $50 \mathrm{mg}$, im) e $2 \mathrm{mg}$ BE im no D0. No D6, $500 \mu \mathrm{g}$ cloprostenol, 300 UI eCG e $1 \mathrm{mg}$ CE foram administradas im. A IATF foi realizada $48 \mathrm{~h}$ após o CE. No grupo dispositivo, $65 \%(13 / 20)$ e no grupo injetável $75 \%(12 / 16)$ das vacas apresentaram folículos $\geq 5 \mathrm{~mm}$ no D4 (p>0,05). A taxa média de crescimento folicular foi de $0,92 \pm 0,25 \mathrm{~mm} /$ dia para o grupo dispositivo e $1,06 \pm 0,45 \mathrm{~mm} / \mathrm{dia}$ para

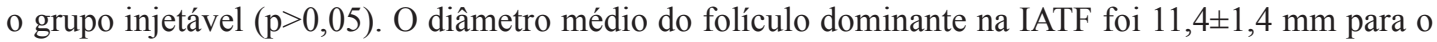
grupo dispositivo e 10,8 $\pm 1,8 \mathrm{~mm}$ para o injetável $(\mathrm{p}>0,05)$. O diâmetro médio do folículo ovulatório

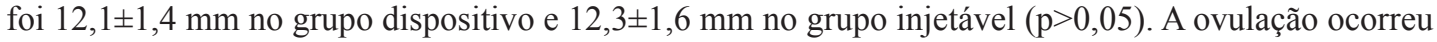
em $90 \%(18 / 20)$ do grupo dispositivo e 37,5\% (6/16) do grupo injetável $(\mathrm{p}<0,05)$. O diâmetro médio do corpo lúteo foi $18,7 \pm 4,3 \mathrm{~mm}$ para o grupo dispositivo e $17,7 \pm 3,6 \mathrm{~mm}$ para o grupo injetável. A P4 injetável mostrou semelhança na presença de folículos $\geq 5 \mathrm{~mm}$ no D4, na taxa de crescimento folicular, no diâmetro do FD, do FO e do CL. No entanto, a taxa de ovulação foi maior no grupo dispositivo.

Palavras-chave: Bos indicus, ultrassonografia, crescimento folicular, ovulação, folículo dominante

\section{Introduction}

Most programs of FTAI in cattle use progesterone (P4) or progestin as the principal hormonal basis for synchronizing the estrous cycle, treatment may be administered in the form of an intravaginal device, an ear implant or an oral medication. The purpose of P4 in FTAI protocols is to promote synchronization of estrus by mimicking a corpus luteum (CL) or prolonged luteal phase (BARUSELLI et al., 2004).

The intravaginal device contains natural P4 that exerts negative feedback on estradiol and inhibits the LH surge during the treatment period (5-10 days), thereby preventing estrus and ovulation of the dominant follicle (DF); (STOCK; FORTUNE, 1993; SAVIO et al., 1993). When associated with estrogen, P4 promotes regression of the DF and the synchronized emergence of a new follicular wave (BARUSELLI et al., 2004). If given with PGF $2 \alpha$ promotes synchronization of estrus and when associated with estradiol, GnRH or LH promotes synchronization of ovulation (BÓ et al., 2002).

Although estradiol/P4-based FTAI protocols are highly efficient in synchronizing Bos indicus cows (SÁ FILHO et al., 2010; SALES et al., 2012) all progress to facilitate reproductive management, minimize service, and reduce costs are necessary considering new advances in reproductive biotechnology. In this respect, the use of an injectable P4 source could become interesting, considering a single parenteral application and absence of sanitary problem as observed with devices (device loss, vaginitis, vulvovaginits etc.). Additionally, it this would be one more alternative to be used not only in the FTAI as in other reproductive biotechnologies, besides adding knowledge about the injectable source, very scarce in the literature.

The isolated effect of injectable P4 on the estrous cycle of cattle has been investigated in a few studies (ULBERG; LINDLEY, 1960; FIKE et al., 1999), but to date no studies have investigated the use of injectable P4 to replace another source of P4 in FTAI protocols in cattle, especially in Bos indicus. The aim of this study was to show the first results of ovarian follicular dynamics of Nelore cows subjected to FTAI protocols using injectable P4 (single parenteral application) or an intravaginal device.

\section{Materials and Methods}

\section{Site, animals and feed management}

The experiment was conducted during the breeding season (November to March) in South America, latitude $23^{\circ} 24^{\prime} 23^{\prime \prime}$ and longitude $57^{\circ}$ $26^{\prime} 4^{\prime \prime}$. The climate in this region is tropical, with an average temperature of $24^{\circ} \mathrm{C}$ and a rainy season from November to January.

Thirty six multiparous Nelore cows (Bos indicus) between 72 and 84 months of age were used for the study. These cows with 45 to 60 days postpartum, had a body condition score (BCS) between 2.5 and 3.5 (2.6 \pm 0.2 ) using a scale of 0 to 5 (AYRES et al., 2009). The average weight of these cows was $448.9 \pm 39.7 \mathrm{~kg}$. 
During the experimental period, the cows were maintained by continuous grazing of Brachiaria brizantha and Brachiaria humindicula. They were given access to mineralized salt and water ad libitum.

\section{Animal selection}

The cows were previously selected according ovarian activity. Palpation and transrectal ultrasonography using an Aloka ultrasound, model SSD-500, equipped with a $5 \mathrm{MHz}$ linear transducer (Aloka, Tokyo, Japan) were performed to select only the cows with absence of CL and large follicles
(<8 mm); (BARUSELLI et al., 2004).

\section{Experimental design}

The animals were randomly allocated into two in groups: 20 cows were subjected to conventional FTAI and another 16 animals received the injectable protocol as outlined in Fig. 1. In the injectable group, FTAI was performed on D8, $48 \mathrm{~h}$ after administration of EC (D6). The injectable protocol was established according to the results of previous studies of our search group. Only the P4 was different between groups.

Figure 1. Schema of the FTAI protocol used for cows that received the intravaginal P4 device or injectable P4, including a schedule of ultrasound evaluations.

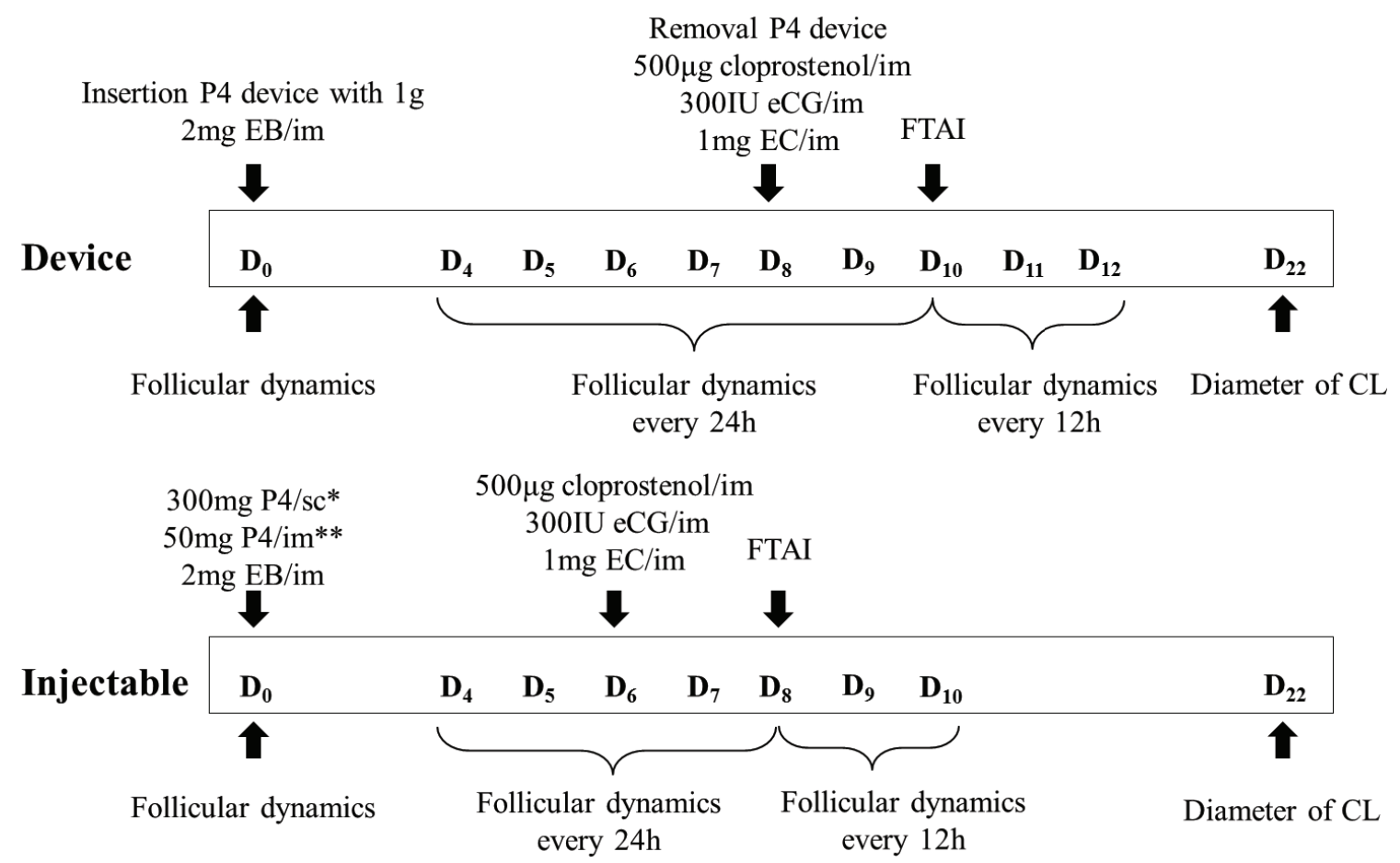

Device group, 20 cows received an intravaginal device with $1 \mathrm{~g}$ of P4 and administration of 2 mg estradiol benzoate (EB) intramuscularly (im) on D0. The device was removed on D8, followed by administration of $500 \mu \mathrm{g}$ of cloprostenol, $300 \mathrm{IU}$ of equine chorionic gonadotropin (eCG) and $1 \mathrm{mg}$ of estradiol cypionate (EC), im. The cows were inseminated 48h later. Injectable group, $350 \mathrm{mg}$ of P4 (300 mg subcutaneously* and $50 \mathrm{mg} \mathrm{im**)}$ and $2 \mathrm{mg}$ of EB im were administered on D0 to 16 cows. On D6, $500 \mu \mathrm{g}$ of cloprostenol, $300 \mathrm{IU}$ of eCG and $1 \mathrm{mg}$ of EC were administered im. The FTAI was performed $48 \mathrm{~h}$ later. P4 - Progesterone (DIB $®$, Syntex, Buenos Aires, Argentina). EB - Estradiol benzoate (Syntex ${ }^{\circledR}$, Syntex, Buenos Aires, Argentina). Cloprostenol (Cyclase ${ }^{\circ}$ DL, Syntex, Buenos Aires, Argentina). eCG - Equine chorionic gonadotropin (Novormon $\AA$, Syntex, Buenos Aires, Argentina). EC - Estradiol cypionate (Cipiosyn ${ }^{\circledR}$, Syntex, Buenos Aires, Argentina). * Natural progesterone in vehicle sesame and peanut oil (slow absorption). ** Natural progesterone in vehicle sesame and peanut oil (fast absorption). Both prepared in the laboratory only for studies.

Source: Elaboration of the authors. 


\section{Follicular dynamics}

Evaluation of follicular dynamics was performed by transvaginal ultrasonography using an Aloka ${ }^{\circledR}$ ultrasound, SSD-500, equipped with a 7.5 MHz micro convex transducer (Aloka, Tokyo, Japan) and coupled to a follicular aspiration guide.

During the evaluation of follicular dynamics, the following parameters were assessed: the presence of follicles $\geq 5 \mathrm{~mm}$ on $\mathrm{D} 4$, the diameter of the dominant follicle (DF) at FTAI, the diameter of the ovulatory follicle (OF), the ovulation rate and the average diameter of the CL. All data were obtained in both ovaries and recorded individually for further monitoring.

For each evaluation, both ovaries were scanned by ultrasound. Follicles $\geq 5 \mathrm{~mm}$ were identified and measured by ultrasound own resources, taking into account the average of two cross-sectional linear measurements of the follicular antrum (GINTHER; KNOPF; KASTELIC, 1989).

The DF was defined as the one that grew to at least $>8 \mathrm{~mm}$ and exceeded the diameter of all other follicles (FIGUEIREDO et al., 1997). Ovulation was monitored by ultrasound every $12 \mathrm{~h}$ after FTAI, detected by the absence of the previously identified DF and confirmed by the later presence of a CL in the same ovary (GINTHER; KNOPF; KASTELIC, 1989).

On the 12th day after FTAI, the diameter of the CL was measured in the same ovary that previously contained the DF. The diameter of the CL was determined by the average of two linear measurements of the cross-sectional surface of the CL (GINTHER; KNOPF; KASTELIC, 1989).

\section{Parameters evaluated and statistical analyses}

The groups were evaluated for the presence of follicles $\geq 5 \mathrm{~mm}$ on $\mathrm{D} 4(\%, \mathrm{~mm})$, the average rate of follicular growth $(\mathrm{mm} /$ day), the diameter of the
DF at FTAI (mm), the diameter of the OF $(\mathrm{mm})$, the ovulation rate $(\%)$ and the average diameter of the CL (mm).

Individual information from each cow was collected in a data set for statistical analysis. The average rate of follicular growth was calculated for each cow of each group according Figueiredo et al. (1997).

Quantitative variables such as average rate of follicular growth, diameter of the DF at FTAI, and diameter of the OF and CL were assessed by analysis of variance (ANOVA). If the difference between groups (P4 device vs. P4 injectable) was significant, data were examined by Student $\mathrm{T}$ test. Frequency data such as the presence of follicles $\geq$ $5 \mathrm{~mm}$ on D4 and ovulation rate were analyzed by Fisher's exact test.

All data were analyzed using the Statistical Software MNITAB15 program. The significance level for rejecting the $\mathrm{H} 0$ (null hypothesis) was $5 \%$; namely, a level of significance $<0.05$ was considered to be the effect of categorical variables and their interactions. Data are given as the mean +/- one standard deviation $(\mathrm{M} \pm \mathrm{SD})$.

\section{Results}

The ultrasonography performed on D4 showed that follicles $\geq 5 \mathrm{~mm}$ were present in $65 \%$ of cows $(13 / 20)$ from the device group and $75 \%$ of cows $(12 / 16)$ from the injectable group $(\mathrm{p}=0.718)$, with a mean follicular diameter of $5.9 \pm 0.6$ and $6.5 \pm 0.7$ $\mathrm{mm}$, respectively $(\mathrm{p}=0.086)$.

The ovulation rate up to $48 \mathrm{~h}$ after FTAI was $90 \%(18 / 20)$ for the device group and $37.5 \%(6 / 16)$ for the injectable group $(\mathrm{p}=0.001)$. In the device group, ovulation occurred at the following times: 0 to $12 \mathrm{~h}, 5 \%(1 / 20) ; 12$ to $24 \mathrm{~h}, 70 \%(14 / 20) ; 24$ to $36 \mathrm{~h}, 15 \%(3 / 20)$; and no ovulation from 36 to $48 \mathrm{~h}$. There was no ovulation from 0 to $12 \mathrm{~h}$ in the injectable group; however, ovulation was later 
observed in $18.8 \%(3 / 16)$ between 12 and $24 \mathrm{~h}$, $6.2 \%(1 / 16)$ between 24 and $36 \mathrm{~h}$ and $12.5 \%(2 / 16)$ between 36 and $48 \mathrm{~h}$.
Table 1 shows the diameter of the DF at FTAI, diameter of the $\mathrm{OF}$ and the diameter of the CL as the mean $\pm \mathrm{SD}$.

Table 1. Average diameter of the dominant follicle (DF) at FTAI, ovulatory follicle (OF) and corpus luteum (CL) of Nelore cows synchronized with protocol-based injectable P4 or intravaginal P4 device.

\begin{tabular}{llll}
\hline \multirow{2}{*}{ Variables } & Groups & p-value \\
\cline { 2 - 3 } & Device & Injectable & \\
\hline Average diameter of the DF at FTAI $(\mathrm{mm})$ & $11.4 \pm 1.4$ & $10.8 \pm 1.8$ & 0.320 \\
$\%$ total of follicles $8.5-11 \mathrm{~mm}$ at FTAI & 35 & 50 & - \\
$\%$ total of follicles $11.1-14.4 \mathrm{~mm}$ at FTAI & 65 & 50 & - \\
\hline Average diameter of the OF $(\mathrm{mm})$ & $12.1 \pm 1.4$ & $12.3 \pm 1.6$ & 0.880 \\
- rate of OF from $8.5-11 \mathrm{~mm}$ & $28 \%(5 / 18)$ & $17(1 / 6)$ & - \\
- rate of OF from $11.1-14.4 \mathrm{~mm}$ & $67 \%(12 / 18)$ & $83(5 / 6)$ & - \\
- rate of OF $>14.4 \mathrm{~mm}$ & $6 \%(1 / 18)$ & - & - \\
\hline Average diameter of CL $(\mathrm{mm})$ & $18.7 \pm 4.3$ & $17.7 \pm 3.6$ & 0.581 \\
\hline
\end{tabular}

Source: Elaboration of the authors.

\section{Discussion}

To our knowledge, this is first study about ovarian follicular dynamics of Nelore cows subjected to FTAI protocols using injectable P4. We also described the used FTAI protocol with injectable P4 and first results of follicular dynamics. It is expected that this information contribute to better understanding of the use of injectable P4. Additionally, we noticed that the major advantage of injectable P4 is the reduction of labor when it is used on a large scale, mainly due the facility of application route.

The FTAI protocol with injectable P4 showed similar follicular dynamics compared to the cows synchronized with an intravaginal device. However, the injectable group showed lower ovulation rate, possibly due to progesterone metabolism.

In the present study, the exact time of follicular emergence was not determined, however, the data of presence of follicles $\geq 5 \mathrm{~mm}$ on D4 demonstrated that injectable $\mathrm{P} 4$ was effective in producing a follicular wave, when $65 \%$ of cows in the device group showed follicles with a mean diameter of
$5.9 \pm 0.6 \mathrm{~mm}$ and $75 \%$ of cows injectable group had follicles with a mean diameter of $6.5 \pm 0.7 \mathrm{~mm}$.

The average rate of follicular growth in our study was $0.9 \pm 0.2 \mathrm{~mm} /$ day for the device group and $1.0 \pm 0.4 \mathrm{~mm} /$ day for the injectable group $(\mathrm{p}=0.248)$. During evaluation of the natural follicular dynamics of multiparous Bos indicus cows, Coutinho et al. (2007) found similar growth rates with $1.0 \pm 0.1 \mathrm{~mm} /$ day in cows with three waves per cycle and $0.8 \pm 0.1$ $\mathrm{mm}$ /day in the cows with two waves per cycle.

To determine a dose of $\mathrm{P} 4$ that allows control of ovarian follicular waves, Callejas et al. (2006) also evaluated the follicular growth rate and diameter of the DF in Bos taurus cows treated with the following daily doses of P4: $600 \mathrm{mg}, 400 \mathrm{mg}$, $200 \mathrm{mg}$ and no P4 (control group). P4 was given im and administered daily from days 3 to 9 of the estrous cycle. The average rate of follicular growth was greater for the control group $(1.63 \pm 0.30 \mathrm{~mm} /$ day) than for $200 \mathrm{mg}(0.56 \pm 0.19 \mathrm{~mm} /$ day $), 400 \mathrm{mg}$ $(0.6 \pm 0.23 \mathrm{~mm} /$ day $)$ and $600 \mathrm{mg}(0.11 \pm 0.13 \mathrm{~mm} /$ day). The control group also demonstrated a greater mean DF diameter $(14.3 \pm 1.3 \mathrm{~mm})$ than groups treated with $\mathrm{P} 4$ doses of $200 \mathrm{mg}(8.8 \pm 1.1 \mathrm{~mm}), 400$ 
$\mathrm{mg}(8.2 \pm 0.8 \mathrm{~mm})$ or $600 \mathrm{mg}(6.6 \pm 0.6 \mathrm{~mm})$. In our experiment, the dose of injectable P4 used (350 mg P4 only on D0) induced follicular growth rates similar to the device group. If compared to study Callejas et al. (2006), was greater than cows given daily P4 and less than those receiving no hormone treatment.

The average diameter of the DF at FTAI was similar between groups, $11.4 \pm 1.4 \mathrm{~mm}$ for the device group and $10.8 \pm 1.8 \mathrm{~mm}$ for the injectable group. In a study of follicular dynamics in Bos taurus beef cows, Mackey et al. (2000) investigated the effect of P4 administration alone or in combination with estradiol, and observed a greater DF diameter than recorded in the present study, with variation from $12.5 \pm 0.6$ to $16.0 \pm 0.7 \mathrm{~mm}$. Higher average has been demonstrated in Bos taurus compared to Bos indicus cows (FIGUEIREDO et al., 1997). In Nelore cows, however, Sales et al. (2012) found an average DF diameter of $13.4 \pm 0.4 \mathrm{~mm}$ at FTAI when ovulation was induced by EB. Siqueira et al. (2009) found similar data in Bos taurus beef cows, which had follicular diameters of $10.5 \pm 0.1$, $10.7 \pm 0.1$ and $10.6 \pm 0.4 \mathrm{~mm}$ when synchronized with intravaginal devices containing $250 \mathrm{mg}$ of medroxyprogesterone acetate, devices containing $250 \mathrm{mg}$ of medroxyprogesterone acetate plus 100 $\mathrm{mg}$ of $\mathrm{P} 4$ given im, or $1 \mathrm{~g}$ of $\mathrm{P} 4$, respectively.

In our study, $65 \%$ of cows from the device group showed follicular diameter between 11.1 and 14.4 $\mathrm{mm}$ and $35 \%$ between 8.5 and $11 \mathrm{~mm}$, very close to other results in Bos indicus females with $\mathrm{P} 4$ device (SÁ FILHO et al., 2010). In the injectable group, $50 \%$ of cows presented with follicles between 11.1 and $14.4 \mathrm{~mm}$ and $50 \%$ between 8.5 and $11 \mathrm{~mm}$. Fewer cows in the injectable group had follicles $>$ $11 \mathrm{~mm}$ at FTAI. The ultrasonography performed 48 $\mathrm{h}$ after FTAI showed that over half of non-ovulating cows continued with DF growth; thus, it is possible that the DF of cow receiving injectable P4 requires a longer growth period.

The injectable group demonstrated a lower ovulation rate than the device group, with only
$37.5 \%(6 / 16)$ ovulating in comparison to $90 \%$ $(18 / 20)$, respectively $(\mathrm{p}=0.001)$. In both groups, most cows that ovulated did so within 12-24 h of FTAI (18.8\% of the injectable and $70 \%$ of the device). In postpartum Nelore cows synchronized with an estradiol/P4-based FTAI protocol, Sales et al. (2012) observed a lower ovulation rate to the device group, with $77.8 \%$ of cows $(21 / 27)$ induced by EB and $82.8 \%(24 / 29)$ by EC. The ovulation rate of the injectable group was lower than observed in the device group or in the literature.

In the device group we observed ovulatory response similar to that reported by (SÁ FILHO et al., 2010). These authors reported that the size of the DF at FTAI has a positive correlation with the ovulation rate. Gimenes et al. (2008) reported that in Bos indicus cattle, the ovulatory response rate is $33 \%, 80 \%$ and $90 \%$ for follicles of $7-8.4 \mathrm{~mm}, 8.5$ - $10 \mathrm{~mm}$ and $>10 \mathrm{~mm}$, respectively.

In the present study, all cows given an intravaginal device responded to the synchronization protocol, and $90 \%$ ovulated. All cows given the injectable P4 also responded to the protocol, presenting with a wave of follicular growth and follicles $>8.5$ mm at FTAI; however, in this group only $37.5 \%$ ovulated. Perhaps it may be influenced by BCS (RODRIGUES et al., 2011), since cows with BCS around 3 had better ovulation rate. Possibly cows with high or low BCS has influence on the P4 injectable metabolism.

The ultrasonography performed $48 \mathrm{~h}$ after FTAI also showed that over half of non-ovulatory cows continued to experience DF growth and in this context some hypotheses could be raised: A longer period of DF growth may enhance the ovulation rate due to greater time for $\mathrm{P} 4$ metabolism. Another possibility would be to test other ovulation inducers, such as GnRH or LH. A study of the plasma profile of injectable $\mathrm{P} 4$ may result in important information to better direct its use in FTAI protocols.

In the present study, the size of the CL was evaluated 12 days after FTAI. Machado et al. (2008) 
reported that the maximum size of the CL occurs between days 13.4 and 14.4 of the estrous cycle, and a maximum concentration of $\mathrm{P} 4$ occurs between days 12.2 and 15.2 .

In summary, postpartum Nelore cows subjected to the FTAI protocol with injectable P4 showed that the presence of follicles $\geq 5 \mathrm{~mm}$ on $\mathrm{D} 4$, follicular growth, diameters of the DF, OF and CL were all similar to those observed in the cows synchronized with an intravaginal device. However, the ovulation rate was higher in the device group, possibly due to peculiarities in the metabolism of injectable P4, resulting in variable levels of LH. Further studies are necessary to better inform the use of injectable P4 in FTAI protocols in Bos indicus females.

\section{Acknowledgements}

We acknowledge to Dr. Renato Castanho Francisco for supporting in this study, to staff of Farm Santa Edwiges (Yby Yaú, Paraguay) for allowing the use of their animals and facilities for this study and to Graduate Program in Animal Science from the State University of Londrina, Londrina, Parana, Brazil. This research was supported by Farm Santa Edwiges and Coordination for the Improvement of Higher Level or Education Personnel (CAPES).

\section{References}

AYRES, H.; FERREIRA, R. M.; TORRES-JÚNIOR, J. R. S.; DEMÉTRIO, C. G. B.; LIMA, C. G.; BARUSELLI, P. S. Validation of body condition score as a predictor of subcutaneous fat in Nelore (Bos indicus) cows. Livestock Science, Philadelphia, v. 123, n. 2-3, p. 175-179, 2009.

BARUSELLI, P. S.; REIS, E. L.; MARQUES, M. O.; NASSER, L. F.; BÓ, G. A. The use of hormonal treatments to improve reproductive performance of anestrous beef cattle in tropical climates. Animal Reproduction Science, Amsterdam, v. 82-83, p. 479-486, 2004.

BÓ, G. A.; BARUSELlI, P. S.; MORENO, D.; CUTAIA, L.; CACCIA, M.; TRIBULO, R.; TRIBULO, H.; MAPLETOFT, R. J. The control of follicular wave development for self-appointed embryo transfer programs in cattle. Theriogenology, Stoneham, v. 57, n. 1, p. 53-72, 2002.

CALLEJAS, S. S.; ALBERIO, R.; CABODEVILA, J.; DULOUT, A. F.; ALLER, J.; CATALANO, R.; TERUEL, M. Influence of different doses of progesterone treatments on ovarian follicle status in beef cows. Animal Reproduction Science, Amsterdam, v. 91, n. 3-4, p. 191200, 2006.

COUTINHO, G. T. R. M.; VIANA, J. H. M.; SÁ, W. F.; CAMARGO, L. S.; FERREIRA, A. M.; PALHÃO, P. M.; NOGUEIRA, L. A. G. Avaliação ultra-sonográfica da dinâmica folicular e lútea em vacas da raça Guzerá. Arquivo Brasileiro de Medicina Veterinária e Zootecnia, Belo Horizonte, v. 59, n. 5, p. 1089-1096, 2007.

FIGUEIREDO, R. A.; BARROS, C. M.; PINHEIRO, O. L.; SOLER, J. M. P. Ovarian follicular dynamics in Nelore breed (Bos indicus) cattle. Theriogenology, Stoneham, v. 47, n. 8, p. 1489-1505, 1997.

FIKE, K. E.; WEHRMAN, M. E.; LINDSEY, B. R.; BERGFELD, G.; MELVIN, E. J.; QUINTAL, J. A.; ZANELLA, E. L.; KOJIMA, F. N.; KINDER, J. E. Estrus synchronization of beef cattle with a combination of melengestrol acetate and an injection of progesterone and 17ß-estradiol. Journal of Animal Science, Champaign, v. 77, p. 715-723, 1999.

GIMENES, L. U.; SÁ FILHO, M. F.; CARVALHO, N. A.; TORRES-JUNIOR, J. R.; SOUZA, A. H.; MADUREIRA, E. H.; TRINCA, L.A.; SARTORELLI, E. S.; BARROS, C. M.; CARVALHO, J. B.; MAPLETOFT, R. J.; BARUSELLI, P. S. Follicle deviation and ovulatory capacity in bos indicus heifers. Theriogenology, Stoneham, v. 69, n. 7, p. 852-858, 2008.

GINTHER, O. J.; KNOPF, L.; KASTELIC, J. P. Temporal association among ovarian events in cattle during oestrus cycles with two and three follicular waves. Journal of Reproduction and Fertility, Cambridge, v. 87, p. 223230, 1989.

MACHADO, R.; BERGAMASCHI, M. A. C. M.; BARBOSA, R. T.; OLIVEIRA, C. A.; BINELLI, M. Ovarian function in Nelore (Bos taurus indicus) cows after post-ovulation hormonal treatments. Theriogenology, Stoneham, v. 69, n. 7, p. 798-804, 2008.

MACKEY, D. R.; SREENAN, J. M.; ROCHE, J. F.; DISKIN, M. G. The effect of progesterone alone or in combination with estradiol on folicular dynamics, gonadotropin profiles, and estrus in beef cows following calf isolation and restricted suckling. Journal of Animal Science, Champaign, v. 78, n. 7, p. 1917-1929, 2000.

RODRIGUES, R. O.; TREVISANUTO, C.; COOKE, R. F.; VASCONCELOS, J. L. M. Effects of body weight loss 
on serum progesterone concentrations of non-lactating dairy cows. Theriogenology, Stoneham, v. 75, n. 1, p. 131-137, 2011.

SÁ FILHO, M. F.; CRESPILHO, A. M.; SANTOS, J. E. P.; PERRY, G. A.; BARUSELLI, P. S. Ovarian follicle diameter at timed insemination and estrus response influences the likelihood of ovulation and pregnancy after synchronization with progesterone or progestinbased protocols in suckled Bos indicus cows. Journal of Animal Science, Champaign, v. 120, n. 1-4, p. 23-30, 2010.

SALES, J. N. S.; CARVALHO, J. B. P.; CREPALDI, G. A.; CIPRIANO, R. S.; JACOMINI, J. O.; MAIO, J. R. G.; SOUZA, J. C.; NOGUEIRA, G. P.; BARUSELLI, P. $\mathrm{S}$. Effects of two estradiol esters (benzoate and cypionate) on the induction of synchronized ovulations in Bos indicus cows submitted to a timed artificial insemination protocol. Theriogenology, Stoneham, v. 78, n. 3, p. 510$516,2012$.
SAVIO, J. D.; TATCHER, W. W.; BADINGA, L.; DE LA SOTA, R. L.; WOLFENSON, D. Regulation of dominant follicle turnover during the oestrous cycle in cows. Journal of Reproduction and Fertility, Cambridge, v. 97, p. 197-203, 1993.

SIQUEIRA, L. C.; OLIVEIRA, J. F.; ROVANI, M. T.; FERREIRA, R.; BORGES, L. F.; GONÇALVES, P. B. Effects of estradiol and progestins on follicular regression before, during, and after follicular deviation in postpartum beef cows. Theriogenology, Stoneham, v. 71, n. 4, p. 614-619, 2009.

STOCK, A. E.; FORTUNE, J. E. Ovarian follicular dominance in cattle: relationship between prolonged growth and the ovulatory follicle and endocrine parameters. Endocrinology, Baltimore, v. 132, n. 3, p. 1108-1114, 1993.

ULBERG, L. C.; LINDLEY, C. E. Use of progesterone and estrogen in the control of reproductive activities in beef cattle. Journal of Animal Science, Champaign, v. 19, n. 4 , p. $1132-1142,1960$. 